\title{
Pembentukan Karakter Secara Holistik
}

\author{
Saat Safaat \\ saatsafaatali@gmail.com \\ Universitas MH Thamrin Jakarta
}

\begin{abstract}
ABSTRAK
Masalah terbesar yang dihadapi bangsa Indonesia saat ini adalah aspek karakter, dapat dilihat dari kasus-kasus yang selalu bertambah setiap tahunnya mulai dari kasus korupsi, narkoba, perceraian, kesenjangan sosial, pembunuhan, tawuran antar pelajar, serta bentuk kenakalan remaja, pemerasan/kekerasan (bullying), dan berita hoax. Dengan penelitian ini, penulis berusaha untuk menemukan konsep dan gagasan-gagasan yang terkandung dalam al-Qur'an tentang pembentukan karakter secara holistik yang dikaji dan dianalisa dari beberapa ayat yang terdapat dalam al-Qur`an dan penafsiran beberapa ulama mengenai ayat-ayat tersebut yang terdapat dalam kita-kitab tafsir. Membentuk manusia yang berkarakter dapat dilakukan dengan pendidikan yang 'holistik. Karena manusia tidak dapat dipahami sebagai dirinya sendiri, tetapi harus dilihat sebagai bagian dari kehidupan yang saling berhubungan antara satu dan yang lainnya. Pendidikan holistik bertujuan mengembangkan potensi manusia secara menyeluruh dalam berbagai aspek, seperti: akademik, emosi, fisik, sosial, kreatifitas, spritual dan karakter. Pendidikan karakter secara holistik tidak hanya membuat seseorang berakhlak mulia, tetapi juga dapat meningkatkan kualitas akademiknya. Al-Quran secara tegas juga mengatakan manusia adalah mahkluk istimewah ( $\mathrm{fi}$ ahsani taqim) yang memiliki totalitas yang holistik yang harus dididik secara utuh baik intelektual dan karakternya sehingga manusia menjadi mahkluk jasadiyah dan ruhaniyah yang sempurna. Pembentukan karakter secara holistik berbasis Al-Qur`an dapat disimpulkan menjadi dua hal. Pertama, tujuan paling mendasar dari pembentukan karakter adalah untuk membuat seseorang menjadi good and smart. Kedua, pendidikan holistik bertujuan mengembangkan potensi manusia secara menyeluruh dalam berbagai aspek, seperti: akademik, emosi, fisik, sosial, kreatifitas dan spritual. Selain itu, pendidikan holistik mengarahkan peserta manusia yang menjadi pribadi mandiri dan berkarakter. Sehingga pendidikan karakter secara holistik tidak hanya membuat seseorang berakhlak mulia, tetapi juga dapat meningkatkan kualitas potensinya
\end{abstract}

Kata Kunci: Karakter, Holistik, Perspektif Al-Quran

\section{Pendahuluan}

Banyak yang mengatakan bahwa masalah terbesar yang dihadapi bangsa Indonesia adalah terletak pada aspek moral. Semakin merosotnya moral bangsa ini dapat dilihat dari kasus-kasus yang selalu bertambah setiap tahunnya mulai dari kasus korupsi, narkoba, perceraian, kesenjangan sosial, pembunuhan, tawuran antar pelajar, serta bentuk kenakalan remaja, pemerasan/kekerasan (bullying), dan yang hangat akhir-akhir ini adalah mengenai berita hoax.

Fakta mencengangkan adalah perilaku seks bebas yang semakin merajalela terutama dikalangan remaja. Berikut adalah data survei dari Komnas PA. Sebanyak 62,7\% remaja SMP tidak perawan dan $21,2 \%$ remaja mengaku pernah aborsi. Perilaku seks bebas pada remaja tersebar di kota dan desa pada tingkat ekonomi kaya dan miskin. Data tersebut didapat berdasarkan survei yang dilakukan Komisi Nasional Perlindungan Anak (Komnas PA), dari 4.726 responden siswa SMP dan SMA di 17 kota besar. Sementara menurut data BKKBN tentang Survei Kesehatan Reproduksi Remaja Indonesia, 
remaja yang mengaku memiliki teman yang pernah berhubungan seksual sebelum menikah pada usia 14-19 tahun mencapai 34,7\% untuk perempuan dan 30,9\% untuk laki-laki.

Kemudian sepanjang tahun 2015 telah terjadi 218 kasus kekerasan seksual pada anak, sementara pada tahun 2016 tedapat 120 kasus kekerasan seksual terhadap anak. Kemudian di tahun 2017 tercatat sebanyak 116 kasus. ${ }^{1}$ Catatan Komisi Pemberantasan Korupsi (KPK) menunjukkan jumlah penyelidikan dan penyidikan kasus korupsi selama 2017 lebih banyak dibanding data 2016. di awal 2018, Komisi Pemberantasan Korupsi (KPK) sudah menjerat lima kepala daerah sebagai tersangka. Sebagian diantaranya dijerat dengan operasi tangkap tangan. Berdasarlan catatan kementrian dalam Negeri sejak 2004 hingga 2017 tidak kurang dari 65 bupati atau walikota, ditambah 12 gubernur tersangkut dengan korupsi. Kementrian Dalam Negeri sendiri mengakui jumlah kepala daerah yang tersangkut korupsi meningkat setiap tahunnya dan menyebar hingga 33 provinsi di Indonesia. ${ }^{2}$

Gambaran situasi masyarakat bahkan situasi pendidikan di Indonesia saat ini justru berbanding terbalik dengan tujuan pendidikan nasional yaitu yang tertuang dalam UUD 1945 (versi Amandemen) Pasal 31, ayat 3 menyebutkan,

"Pemerintah mengusahakan dan menyelenggarakan satu sistem pendidikan nasional, yang meningkatkan keimanan dan ketakwaan serta ahlak mulia dalam rangka mencerdaskan kehidupan bangsa, yang diatur dengan undang-undang."

Pasal 31, ayat 5 menyebutkan, "Pemerintah memajukan ilmu pengetahuan dan teknologi dengan menunjang tinggi nilai-nilai agama dan persatuan bangsa untuk kemajuan peradaban serta kesejahteraan umat manusia."

Tujuan Pendidikan Nasional dalam Undang-Undang No. 20, Tahun 2003, Jabaran UUD 1945 tentang pendidikan dituangkan dalam Undang-Undang No. 20, Tahun 2003. Pasal 3 menyebutkan, "Pendidikan nasional berfungsi mengembangkan kemampuan dan membentuk watak serta peradaban bangsa yang bermartabat dalam rangka mencerdaskan kehidupan bangsa, bertujuan untuk berkembangnya potensi peserta didik agar menjadi manusia yang beriman dan bertakwa kepada Tuhan Yang Maha Esa, berakhlak mulia, sehat, berilmu, cakap, kreatif, mandiri, dan menjadi warga negara yang demokratis serta bertanggung jawab."

Tujuan Pendidikan Menurut UNESCO: Dalam upaya meningkatkan kualitas suatu bangsa, tidak ada cara lain kecuali melalui peningkatan mutu pendidikan. Berangkat dari pemikiran itu, Perserikatan Bangsa-Bangsa (PBB) melalui lembaga UNESCO (United Nations, Educational, Scientific and Cultural Organization) mencanangkan empat pilar pendidikan baik untuk masa sekarang maupun masa depan, yakni: (1) learning to Know, (2) learning to do (3) learning to be, dan (4) learning to live together. Dimana keempat pilar pendidikan tersebut menggabungkan tujuan-tujuan IQ, EQ dan $S Q$.

Dengan demikian pelaksanaan pembentukan karakter secara holistik perlu diimplementasikan sejalan dengan definisi pendidikan yang telah diuraikan di atas yaitu pendidikan harus dapat membentuk manusia secara utuh (holistik) yang mengambungkan IQ, EQ dan SQ sehingga terbangunlah manusia yang sempurna: akal dan hatinya, rohani dan jasmaninya, akhlak dan keterampilannya. Maka akan timbul dalam diri seseorang untuk berlomba-lomba dan memotivasi diri untuk lebih baik dalam segala aspek kehidupan. Pada intinya pendidikan itu bertujuan untuk membentuk karakter seseorang yang beriman dan bertakwa kepada Tuhan Yang Maha Esa.

Di Indonesia pelaksanaan pembentukan karakter saat ini memang dirasakan mendesak. Melihat gambaran situasi masyarakat bahkan situasi dunia pendidikan di Indonesia yang selama ini dirasakan belum berhasil membangun manusia Indonesia yang berkarakter. Bahkan, banyak yang menyebut pendidikan telah gagal karena banyak lulusan sekolah atau sarjana yang piawai dalam menjawab soal ujian, berotak cerdas, tetapi mental dan moralnya lemah.

\footnotetext{
${ }^{1}$ www.kpai.go.id

${ }^{2}$ www.kpk.go.id
} 


\section{Kajian Pustaka}

Dari segi definisi, akar kata karakter berasal dari bahasa Latin, yaitu Kharakter, Khrassein dan Kharax, yang bermakna dipahat, atau tools for marking (alat untuk menandai). Wyne mengungkapkan bahwa kata karakter berasal dari bahasa Yunani "karasso" yang berarti "to mark" yaitu menandai atau mengukir. ${ }^{3}$ Pendapat lain, karakter berasal dari kata Yunani, charassein, yang berarti mengukir sehingga terbentuk sebuah pola. ${ }^{4}$ Memfokuskan bagaimana mengaplikasikan nilai kebaikan dalam bentuk tindakan atau tingkah laku. Oleh sebab itu seseorang yang berperilaku tidak jujur, kejam atau rakus dikatakan sebagai orang yang berkarakter jelek, sementara orang yang berprilaku jujur, suka menolong dikatakan sebagai orang yang berkarakter mulia. Jadi istilah karakter erat kaitannya dengan personality (kepribadian) seseorang.

Sedangkan Karakter menurut Kamus Besar Bahasa Indonesia merupakan sifat-sifat kejiwaan, akhlak atau budi pekerti yang membedakan seseorang dari yang lain. Dengan demikian karakter adalah nilainilai yang unik-baik yang terpateri dalam diri dan terjawantahkan dalam perilaku. Karakter secara koheren memancar dari hasil olah pikir, olah hati, olah rasa dan karsa, serta olahraga seseorang atau sekelompok orang. ${ }^{5}$

Dari pengertian etimologi di atas dapat dipahami bahwa karakter berkaitan erat dengan kepribadian manusia, diartikan sebagai watak, tabiat, akhlak, atau kepribadian seseorang yang terbentuk dari hasil internalisasi berbagai kebajikan yang diyakini dan digunakan sebagai landasan untuk cara pandang, berpikir, bersikap, dan bertindak. Kebajikan terdiri atas sejumlah nilai, moral, dan norma, seperti jujur, peduli dan bertangung jawab yang mana untuk membentuknya memerlukan upaya-upaya yang maksimal, agar menjadi manusia yang mempunyai karakter positif, yang mampu menebarkan kebajikan dalam kehidupan sosial masyarakat, dan berupaya meninggalkan perbuatan-perbuatan yang tidak penting, apalagi dapat merugikan orang banyak.

Sehingga tujuan pembentukan karakter adalah untuk terwujud kesatuan esensial individu dengan prilaku dan sikap hidup yang dimiliki. Karakter merupakan sesuatu yang mengualifikasi seseorang pribadi. Karakter menjadi indentitas yang mengatasi pengalaman kontingen yang selalu berubah dari kematangan karakter, kualitas seorang pribadi diukur.

Oleh sebab itu tujuan paling mendasar dari pembentukan karakter adalah untuk membuat seseorang menjadi good and smart. Nabi Muhammad SAW juga menegaskan bahwa misi utamanya dalam mendidik manusia adalah untuk mengupayakan pembentukan karakter yang baik (good character). Sebagaimana sabda Rasulullah saw:

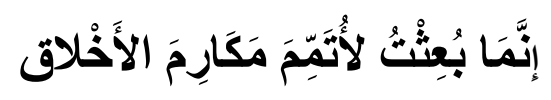

Sesungguhnya aku diutus hanya untuk menyempurnakan kemuliaan ${ }^{6}$ akhlak. (HR Al-Baihaqi dari Abu Hurairah Radhiyallahu 'Anhu).

Pada redaksi hadits lain dikatakan:

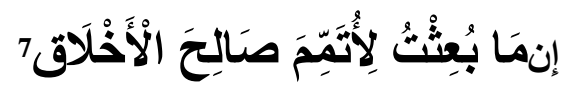

Sesungguhnya aku diutus untuk menyempurnakan keshalehan akhlak yang baik.

${ }^{3}$ Furqon Hidayatullah, Pendidikan Karakter: Membangun Peradaban Bangsa, (Surakarta: Yuma Pustaka, 2010), hal. 12.

${ }^{4}$ Ratna Megawangi, Pendidikan Karakter Solusi yang Tepat untuk Membangun Bangsa, (Bogor: Indonesia Heritage Foundation, 2004), hal. 25.

${ }^{5}$ Kamisa, Kamus Besar Bahasa Indonesia, (Surabaya: Peenerbit Kartika, 2008), hal. 145.

6 Kata makarim dan shalih yang melekat dengan kata akhlak menunjukkan tidak bisa dilepaskan diantara keduanya, yakni kebaikan, keshalihan dan kemuliaan menurut standar ajaran Islam.

${ }^{7}$ HR. Al-Bukhari dalam al-Adabul Mufrad no. 273 (Shahiihul Adabil Mufrad no. 207), Ahmad (II/381), dan al-Hakim (II/613), dari Abu Hurairah Radhiyallahu anhu. Dishahihkan oleh Syaikh al-Albani dalam Silsilatul Ahaadiits ash-Shahiihah (no. 45). 
Keagungan akhlak Nabi SAW, Allah sebutkan di dalam Q.S Al-Ahzab/33: 2,

\author{
"Sesungguhnya telah ada pada (diri) Rasulullah itu suri teladan yang baik bagimu (yaitu) \\ bagi orang yang mengharap (rahmat) Allah dan (kedatangan) hari kiamat dan Dia banyak \\ menyebut Allah".
}

Dari paparan hadist dan ayat di atas dapat disimpulkan bahwa Nabi Muhammad SAW m SAW merupakan Rasul akhir zaman, Rasul terakhir dan penutup para nabi, yang diutus oleh Allah untuk seluruh umat manusia tanpa melihat asal suku dan bangsanya. Misi Nabi Muhammad antara lain adalah menyempurnakan akhlak manusia. Begitulah, Allah mengutus Rasulullah SAW dilengkapi dengan perilaku ( $a k h l a k$ ) yang mulia dan menjadi teladan terbaik bagi umatnya.

Sehinga, dalam melihat kondisi saat ini dapat dikatakan bahwa keberhasilan pendidikan bukan dari sekedar keberhasilan Akademiknya saja, bukan hanya sekedar sederet angka-angka yang tinggi tetapi harus memiliki kemampuan untuk bergaul, bersosialisasi dan memiliki karakter yang baik maka terwujudlah manusia yang good and smart.

\title{
Pendidikan Holistik
}

Kata holistik berasal dari kata "holisme" Asal kata "holisme" diambil dari bahasa Yunani, yang berati semua atau keseluruhan, pertama kali diperkenalkan pada 1926 oleh Jan Smuts, seorang negarawan dari Afrika Selatan dalam bukunya yang berjudul Holism and Evolution. Seperti yang ditulis oleh Shinji Nobira dalam makalah Education For Humanity: Implementig Volues in Holistik Education, bahwa "The Word "holistic" is derived from the "holism". The word "holism" is said to have been first used in "holism and Evoluatio" by. J.C. Smuts written 1926". ${ }^{8}$ Smuts mendefinisikan holisme sebagai sebuah kecendrungan alam untuk membentuk sesuatu yang utuh sehingga sesuatu tersebut lebih besar daripada sekedar gabungan-gabungan bagian hasil evolusi. ${ }^{9}$

Dalam kamus besar bahasa Indonesia kata holisme didefinisikan sebagai cara pendekatan terhadap suatu masalah atau gejala, dengan memandang gejala atau masalah itu sebagai suatu kesatuan yang utuh dari kata holisme itulah kata holistik diartikan sebagai cara pandang yang menyeluruh atau secara keseluruhan. ${ }^{10}$

Dalam ranah pendidikan, pendidikan holistik merupakan suatu metode pendidikan yang membangun manusia secara keseluruhan dan utuh dengan mengembangkan semua potensi manusia yang mencakup potensi sosial, emosi, intelektual, moral, karakter, kreatifitas, dan spritual. ${ }^{11}$ Pendidikan holistik menurut Jeremy Henzell-Thomas yang dikutip oleh Ratna Megawangi merupakan suatu upaya membangun secara utuh dan seimbang pada setiap siswa dalam seluruh aspek pembelajaran, yang mencakup spritual, moral, imajinatif, intelektual, budaya, estetika, emosi dan fisik yang mengarahkan seluruh aspek tersebut ke arah pencapaian sebuah kesadaran tentang hubungannya dengan Tuhan yang merupakan tujuan akhir dari semua kehidupan dunia. ${ }^{12}$

Sehinga berdasarkan pengertian holistik di atas dapat disimpulkan bahwa pendidikan holistik adalah cara memandang pendidikan yang menyeluruh bukan merupakan bagian-bagian yang parsial, terbatas, dan kaku. Jadi, pendidikan holistik tidak semata utuh dari segi tujuan pendidikan. Lebih dari itu, murid harus mampu memahami diri dan lingkungannya: kurikulum, metode, dan pendidikan harus pula diarahkan sesuai karakter dan prinsip-prinsip, serta core pendidikan holistik.

22.

${ }^{8}$ Jejen Musfah (Ed), Pendidikan Holistik Pendekatan Lintas Perspektf, (Jakarta: Kencana, 2012), hal. ${ }^{9}$ Ensikolpedia Bebas, Holisme, dalam https://id.wikepedia.org/wiki/holisme, diakses pada 5 Setember 2016.

${ }^{10}$ Kamus Besar Bahasa Indonesia, (Surabaya: Penebit Kartika, 2008), hal. 250

${ }^{11}$ Ratna Megawangi, Pendidikan Holistik..., hal. 21.

${ }^{12}$ Ratna Megawangi, Pendidikan Holistik..., hal. 20. 


\section{Pembentukan Karakter Secara Holistik Berbasis Al-Quran}

Dalam diri manusia terdapat kemampuan dasar atau potensi yang di bawah sejak lahir, yang tidak berkembang dengan sempurna tanpa melalui jenjang pendidikan. Sehingga pendidikan dalam arti seluas-luasnya sangat diperlukan oleh manusia.

Posisi strategis pendidikan dalam membangun kepribadian utuh ternyata belum diaktualisasikan sepenuhnya dalam dunia pendidikan dewasa ini. Setidaknya ini tercantum dari kegelisahan intelektual yang diungkapkan oleh Komaruddin Hidayat, sebagai berikut: "Dari hasil kajian neuropsokologi, otak manusia tersusun dari berbagai jenis dan bagian yang masing-masing mempunyai dan potensi berbeda. Namun disayangkan, cara belajar orang Indonesia banyak mengandalkan otaka kiri yang bekerja linier, repetitif, analitis, pratikularistik, dan reproduktif. Akibatnya, inteligensi spiritual, emosional dan inteligensi lainya kurang aktif yang pada ururutannya masyarakat semacam ini tidak kreatif dan inovatif dalam membangun peradaban. Yang mengemuka adalah tradisi menghafal, meniru, transfer paragdima berpikir yang monoton dan seragam".

Merespon ungkapan di atas tersebut, maka signifikasi pendidikan holistik menjadi sangat penting untuk diterapkan karena pendidikan holistik bertujuan untuk menggali setiap potensi jati diri dan kemampuan setiap manusia. Tujuan ini searah dengan pendidikan karakter yang saat ini diprogramkan pemerintah, di mana tujuan dari pendidikan karakter adalah terwujudnya kesatuan esensial antara prilaku dan sikap hidup yang dimiliki, di mana esensi pendidikan karakter adalah pendidikan etissprittual.

Pendidikan karakter bukanlah pembelajaran sebuah bidang study tetapi menjadi bagian yang terintegrasi dalam keutuhan semua proses pendidikan yang terwujud dalam pembelajaran. Pendidikan karakter bukanlah sesuatu hal yang baru dari sistem pendidikan nasional, sebab UU No. 20/2003 tentang Sisdiknas sudah terkandung amanah pendidikan karakter. Namun dalam perjalanannya, pendidikan holistik berbasis karakter belum menjadi ruh dari setiap jenjang pendidikan. National and character bulding dalam membangun bangsa ini adalah hal yang sangat filosofis dan menyangkut pengembangan esensi pembangunan manusia seutuhnya.

Socrates sekitar 2500 tahun yang lalu meneriakkan bahwa tujuan paling mendasar dari pendidikan atau filosofi dasar pendidikan adalah menjadikan seseorang good and smart. Good dalam aspek karakter dan smart dari segi intelektual. Filosofi ini tereflesikan pada tujuan pendidikan, yaitu mengembangkan seluruh potensi manusia secara holistik. Tujuan pendidikan tersebut sejalan dengan tujuan dari pendidikan holistik, yaitu membentuk manusia holistik. Manusia holistik adalah manusia yang mampu mengembangkan seluruh potensi yang ada dalam dirinya. Potensi yang ada dalam diri setiap manusia meliputi: aspek fisik, aspek emosi, aspek sosial, aspek kreativitas, aspek spritual, aspek akademis, dan moral atau karakter. Dan ini sejalan dengan firman Allah dalam QS AtTien/95:4,

\section{"Sesungguhnya Kami telah menciptakan manusia dalam bentuk yang sebaik-baiknya" Dalam Q.S As-Sajdah/32:7, Allah swt berfirman: \\ "Yang membuat segala sesuatu yang Dia ciptakan sebaik-baiknya dan yang memulai penciptaan manusia dari tanah."}

Dalam ayat di atas menjelaskan bahwa Allah swt menciptalan manusia dengan sebaik-baiknya bentuk. Secara fisik manusia memiliki struktur tubuh yang sempurna ditambah dengan pemberian akal, maka jadilah manusia makhluk jasadiyah dan ruhaniyah yang sempurna (utuh).

Buya Hamka menyampaikan bahwa sebaik-baik bentuk yang disampaikan dalam ayat ini bukan hanya berkaitan dengan persoalan kondisi fisik, tapi meliputi seluruh potensi yang Allah berikan baik potensi lahir maupun batin. ${ }^{13}$

Melalui potensi inilah setiap manusia sesungguhnya dapat meraih keistimewaan dan kemuliaan dirinya manakalah potensi itu dapat dikelola dengan baik dan benar. Namun sebaliknya, jika potensi

${ }^{13}$ Hamka, Tafsir Al-Azhar, (Singapura: Kerjaya Printing Industrie Pte Ltd, 2003) cet. Kelima, hal. 8050. 
tersebut tidak diasah dan digunakan dengan sebaik-baiknya maka akan yang membuat manusia jatuh dalam kehinaan.

Dalam sebuah hadis Nabi Muhammad SAW juga menegaskan sebagaimana dalam hadis diriwiyatkan oleh Imam Muslim dari Abu Hurairah,

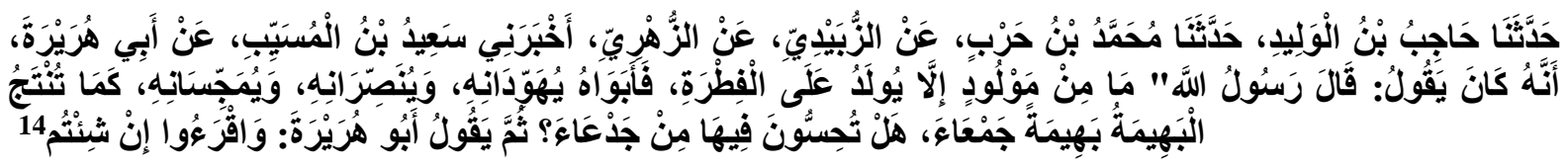

Hâjib bin al-Walid menceritakan kepada kami (dengan mengatakan) Muhammad bin harb menceritakan kepada kami (yang berasal) dari al-Zubaidi (yang diterima) darfi al-Zuhri (yang mengatakan) Sa'id bin al-Musayyab memberitahukan kepadaku (yang diterima) dari Abu Hurairah bahwa ia berkata, Rasulullah saw bersabda: "Setiap anak lahir (dalam keadaan) fitrah, kedua orang tuanya (memiliki andil dalam) menjadikan anak beragama Yahudi, Nasrani, atau bahkan beragama Majusi, sebagaimana binatang ternak memperanakkan seekor binatang (yang sempurna anggota tubuhnya). Apakah anda mengetahui di antara binatang itu ada yang cacat/putus (telinganya atau anggota tubuhnya yang lain). (HR.Muslim).

Dalam hadis di atas menjelaskan bahwa manusia dilahirkan dengan fitrah, dalam pengertian yang sederhana fitrah sering dimaknai dengan suci. Sedangkan dalam hal ini penulis memaknai fitrah dengan dengan pengertian potensi. Asal kata fitrah berasal dari kata (fi ill) fathara (فطرة) jamaknya fithar (فطر) yang berati "menjadikan" fitrah berati kejadian asli, agama, ciptaan, sifat semula jadi, potensi dasar. ${ }^{15}$ Hasan Langulung mengatakan bahwa Allah menyertakan anak yang baru lahir itu "fitrah" yang diartikan sebagai potensi. ${ }^{16}$

Manusia diciptakan Allah dalam struktur yang paling baik diantara makhluk Allah yang lain. Dalam unsur ini Allah memberikan seperangkat kemampuan dasar yang memiliki kecenderungan, dalam psikologi disebut potensialitas atau disposis. ${ }^{17}$ Yang menurut pandangan al-Qur'an dinamakan "Fitrah", Manusia dilahirkan dengan membawa fitrah-fitrah tertentu. Fitrah berarti kekuatan terpendam yang ada dalam diri manusia, dibawa semenjak lahir dan akan menjadi daya pendorong bagi kepribadianya

Dengan demikian manusia sebagai makluk sempurna harus dididik secara utuh baik intelektual dan karakternya sehingga tokoh pendidikan Barat yang mendunia, Marthin Luther King mengatakan bahwa, "Intelligence plus character, that is the true aim of education." Sehingga muncul kualitas karakter manusia yang berkembang secara holistik:

1. Selalu ingin tahu dan bertanya (inquirer); sifat alami manusia yang selalu bertanya dan ingin tahu tumbuh subur pada dirinya, sehingga kecintaannya untuk terus belajar menjadi sifat alaminya yang terbawa sampai tua.

2. Berpikir kritis dan kreatif (critical and creative thinkers); mampu untuk melihat masalah dari berbagai sudut pandang, sehingga dapat mengambil keputusan dengan bijak dan menyelesaikan masalah yang sangat kompleks. Selain itu mampu mengumpulkan, menganalisis, dan mengevaluasi secara kritis segala informasi yang diperoleh.

3. Berpengetahuan luas (knowled geable); mempunyai ketertarikan yang besar pada masalahmasalah global yang relevan dan penting, sehingga selalu meluangkan waktu untuk

${ }^{14}$ Ibnu Hajar al-Asqalani, Fathul Bahri, (penjelasan kitab Shahih al-Bukhari). Terj. Amiruddin, Jilid VII, (Jakarta: Pustaka Azzam, 2008), hal. 344

${ }^{15}$ Muhammad Fuad Abdul Baql, Al-Mu jamal-Mufaharas li Alfaz Al-Quran Al-Karim (Beirut: Dai Ihya` al-Turas al-Arabi, tt), hal. 522-533.

${ }^{16}$ Hasan Langulung, Pendidikan dan Peradaban Islam, (Jakarta: Pustaka Al-Husna Zikra, 1985), hal. 215.

${ }^{17}$ M. Arifin, Ilmu Pendidikan Islam, (Jakarta: PT Bumi Aksara, 1991), hal. 42. 
membaca dan mengeksplorasi bidang-bidang yang diminatinya. Pengetahuannya tentang sesuatu menjadi solid dan membumi.

4. Komunikator yang efektif (effective communicator); mampu mengekspresikan pikiran dan perasaannya dengan efektif, baik secara verbal maupun tertulis. Dengan bekal pengetahuan yang luas, segala informasi dapat dikomunikasikan dengan percaya diri dan meyakinkan.

5. Berani mengambil resiko (risk taker); segala tantangan baru dihadapi dengan optimis dan percaya diri, serta berani mencoba menggunakan ide dan strategi baru dalam menjawab tantangan dan rintangan yang ada.

6. Bersikap terbuka terhadap segala perbedaan yang ada (open-minded); dapat menghormati pendapat, nilai, dan tradisi yang berbeda. Mengerti bahwa manusia mempunyai latar belakang budaya beragam, dan dapat mengambil keputusan dengan mempertimbangkan perbedaanperbedaan tersebut.

7. Peduli kepada orang lain dan lingkungan sekitar (caring); sensitif terhadap kebutuhan dan perasaan orang lain, serta lingkungannya (sosial, ekonomi, dan alam). Mempunyai komitmen terhadap kegiatan sosial, dan senantiasa memberikan nilai tambah kepada lingkungannya (added value).

8. Mempunyai integritas moral (integrity); memegang teguh prinsip moral, kejujuran, bersikap obyektif dan adil.

9. Mempunyai kesadaran spiritual; bahwa dirinya adalah bagian dari keseluruhan dan mengerti bahwa apapun yang dilakukannya akan membawa konsekuensi kepada lingkungannya. Mampu untuk melihat kekurangan/kelebihan dirinya, serta mempunyai rasa (interconnection) (silaturahmi, baik dengan Allah swt, manusia maupun alam), dan compassion (rasa kasih sayang dan kepedulian).

Pembentukan karakter yang saat ini menjadi salah satu perhatian kuat mendikbud, harus diletakan dalam bingkai utuh sistem pendidikan nasional sebagai rujukan normatif penyelengaraan pendidikan nasional, dengan mengacu pada prinsip-prinsip sebagai berikut:

1. Karakter adalah sebuah keunikan yang melekat pada individu, kelompok, masyarakat, atau bangsa. Namun karakter bangsa bukanlah agregasi karakter perorangan, karena karakter bangsa harus terwujud dalam kebangsaan yang kuat, berlandaskan pada core values yang bersifat universal dalam konteks kultur yang beragam. Karakter bangsa bersifat universal dalam konteks kultur yang beragam. Karakter bangsa mengandung perekat kultural, yang harus terwujud dalam kesadaran kultural (culutural awarness) dan kecerdasan kultural (cultural intelligence) setiap warga negara.

2. Pembentukan karakter adalah sebuah proses berkelanjutan dan tidak pernah berakhir (never ending proces) selama sebuah bangsa ada dan inggin tetap eksis.

3. Pasal 1 (3) dan Pasal 3 UU N0. 20/2003 tentang Sisdiknas adalah landasan legal formal akan keharusan membangun karakter bangsa melalui upaya pendidikan.

4. Proses pembelajaran sebagai wahana pendidikan dan pengembangan karakter yang terpisahkan dari pengembangan kemampuan sains, teknologi, dan seni telah dirumuskan secara sangat bagus sebagai landasan legal pengembangan pembelajaran dalam Pasal1 (1) UU N0. 20/2003.

5. Proses pembentukan karakter akan melibatkan ragam aspek perkembangan peserta didik, baik kognitif, konatif, afektif, maupun psikomotorik sebagai suatu kesatuan (holistik) dalam konteks kehidupan kultural.

6. Sekolah sebagai ekologi pembudayaan peserta didik dan guru sebagai "perekayasa" kultur sekolah tidak terlepas dari regulasi, kebijakan, dan birokrasi.

7. Pembentukan karakter adalah pendidikan sepanjang hayat, sebagai proses perkembangan ke arah manusia kaffah.

8. Pembentukan karakter akan harus bersifat multilevel, multichanel, multisetting karena tidak mungkin hanya dilaksanakan oleh sekolah, tetapi menjadi sebuah gerakan moral yang bersifat holistik. 
Dengan demikian yang dinamakan pembentukan karakter secara holistik adalah pendidikan yang tidak hanya membuat seseorang berkarakter mulia, tetapi juga dapat meningkatkan dan menumbuhkan seluruh potensinya. Relasi antara keberhasilan pembentukan karakter dan pendidikan holistik dapat menumbuhkan susana sekolah atau lembaga pendidikan menjadi menyenangkan dan proses pembelajaran yang kondusif.

\section{Kesimpulan}

Dari pemaparan di atas pembentukan karakter secara holistik berbasis Al-Qur`an dapat disimpulkan menjadi dua hal. Pertama, tujuan paling mendasar dari pembentukan karakter adalah untuk membuat seseorang menjadi good and smart. Pembentukan karakter adalah untuk terwujud kesatuan esensial individu dengan prilaku dan sikap hidup yang dimiliki. Karakter merupakan sesuatu yang mengualifikasi seseorang pribadi. Karakter menjadi indentitas yang mengatasi pengalaman yang selalu berubah dari kematangan karakter, kualitas seorang pribadi diukur. Kedua, pendidikan holistik bertujuan mengembangkan potensi manusia secara menyeluruh dalam berbagai aspek, seperti: akademik, emosi, fisik, sosial, kreatifitas dan spritual. Selain itu, pendidikan holistik mengarahkan peserta manusia yang menjadi pribadi mandiri dan berkarakter. Sehingga pendidikan karakter secara holistik tidak hanya membuat seseorang berakhlak mulia, tetapi juga dapat meningkatkan kualitas potensinya.

\section{Daftar Pustaka}

Furqon Hidayatullah, 2010, Pendidikan Karakter: Membangun Peradaban Bangsa, Surakarta: Yuma Pustaka.

Ratna Megawangi, 2004, Pendidikan Karakter Solusi yang Tepat untuk Membangun Bangsa, Bogor: Indonesia Heritage Foundation.

Kamus Besar Bahasa Indonesia, 2008, Surabaya: Penerbit Kartika

Al-Bukhari dalam al-Adabul Mufrad no. 273 (Shahiihul Adabil Mufrad no. 207), Ahmad (II/381), dan al-Hakim (II/613), dari Abu Hurairah Radhiyallahu anhu. Dishahihkan oleh Syaikh al-Albani dalam Silsilatul Ahaadiits ash-Shahiihah (no. 45).

Jejen Musfah (Ed), 2012, Pendidikan Holistik Pendekatan Lintas Perspektf, Jakarta: PT. Kencana.

Ensikolpedia Bebas, 2016 Holisme, dalam https://id.wikepedia.org/wiki/holisme,

Hamka, Tafsir Al-Azhar, 2003, Singapura: Kerjaya Printing Industrie Pte Ltd

Ibnu Hajar al-Asqalani, 2008, Fathul Bahri, (penjelasan kitab Shahih al-Bukhari). Terj. Amiruddin, Jilid VII, Jakarta: Pustaka Azzam.

Muhammad Fuad Abdul Baql, Al-Mu jamal-Mufaharas li Alfaz Al-Quran Al-Karim, Beirut: Dai Ihya` al-Turas al-Arabi, tt.

Hasan Langulung, 1985, Pendidikan dan Peradaban Islam, Jakarta: Pustaka Al-Husna Zikra.

M. Arifin, 1991, Ilmu Pendidikan Islam, Jakarta: PT Bumi Aksara.

www.kpai.go.id

www.k pk.go.id 